\title{
Advancing Faculty Diversity Through Self-Directed Mentoring
}

\author{
By YVONnE M. DutTon, MARGARET RYZNAR, AND LEA SHAVER*
}

\begin{abstract}
Mentoring is widely acknowledged to be important in career success, yet may be lacking for female and minority law professors, contributing to disparities in retention and promotion of diverse faculty. This Article presents the results of a unique diversity mentoring program conducted at one law school. Mentoring is often thought of as something directed by the mentor on behalf of the protégé. Our framework inverts that model, empowering diverse faculty members to proactively cultivate their own networks of research mentors. The studied intervention consisted of modest programming on mentorship, along with supplemental travel funds to focus specifically on travel for the purpose of cultivating mentors beyond one's own institution. Participants were responsible for setting their own mentorship goals, approaching mentors and arranging meetings, and reporting annually on their activities and progress. Both quantitative and qualitative evidence demonstrate that the program has been effective along its measurable goals in its first year. Participants report growing their networks of mentors, receiving significant advice on research and the tenure process, and being sponsored for new opportunities. The authors conclude that this type of mentoring initiative, if more broadly applied, could have a significant impact on reducing disparities in retention and promotion in the legal academy. To facilitate such replication, the Article describes both the process of designing the program and the actual operation of the program as carried out at one school. In sum, the Article offers a concrete starting point for discussions at any law school interested in advancing faculty diversity through improved mentoring.
\end{abstract}

Copyright (C) 2017 by Yvonne M. Dutton, Margaret Ryznar, and Lea Shaver

* Associate Professor, Associate Professor, and Professor of Law (respectively), Indiana University Robert H. McKinney School of Law. The authors would like to thank their institution and colleagues and the IUPUI Mentoring Academy for contributing to the design and execution of the mentoring initiative upon which this study is based. For their helpful comments on drafts of this article, the authors would like to thank Kevin Johnson, Florence Wagman Roisman, and Nicholas L. Georgakopoulos. For excellent research assistance, the authors would like to thank librarian Benjamin Keele. The authors contributed equally to this article and appear in alphabetical order. This article is available for public use under the terms of a Creative Commons Attribution 4.0 International license. You are free (and encouraged) to share, translate, excerpt, record, or otherwise adapt this work, so long as you give credit to the authors and to the Duke Journal of Gender Law \& Policy. 


\section{INTRODUCTION}

For decades, there have been calls for law schools to increase faculty diversity, particularly among the schools' tenured and leadership ranks. ${ }^{1}$ The institutional benefits of faculty diversity for law schools-in both teaching and scholarship-are well documented. ${ }^{2}$ Research in the corporate context also

1. See, e.g., Kevin R. Johnson, How and Why We Built a Majority-Minority Faculty, Chronicle of Higher Education, July 26, 2016, at http://www.chronicle.com/article/HowWhy-We-Built-a/237213 [https://perma.cc/V4KY-8JB9] [hereinafter How and Why]; Loftus C. Carson, II, Employment Opportunities and Conditions for the African-American Legal Professoriate: Perspectives from the Inside, 19 TEX. J. C. L. \& C. R. 1, 8-10 (2013) (discussing the benefits of increasing the number of tenured AfricanAmerican, and other faculty of color in American law schools); Kevin R. Johnson, The Importance of Student and Faculty Diversity in Law Schools: One Dean's Perspective, 96 IOWA L. REV. 1549 (2011) [hereinafter One Dean's Perspective] (summarizing the benefits of faculty diversity to legal scholarship and teaching, as well as arguing that faculty and student diversity are components of law school excellence that merit inclusion in the U.S. News \& World Report rankings methodology); Ann C. McGinley, Reproducing Gender on Law School Faculties, 2009 B.Y.U. L. REV. 99, 116-18, 123-125 (2009) (criticizing a gender divide in law schools whereby women are hired into lower-paying, lower-status faculty positions); Marjorie E. Kornhauser, Rooms of Their Own: An Empirical Study of Occupational Segregation By Gender Among Law Professors, 73 U.M.K.C. L. REV. 293, 294-95 (2004) (noting that women hold fewer prestigious positions in the legal academy, which deleteriously affects law students and the legal profession); Jon C. Dubin, Faculty Diversity as a Clinical Legal Education Imperative, 51 HASTINGS L.J. 445 (2000); Randall Kennedy, In Praise of the Struggle for Diversity on Law School Faculties, 22 SETON HALL L. REV. 1389 (1992), available at http://chicagounbound.uchicago.edu/cgi/viewcontent.cgi?article=1087\& context=uclf [https://perma.cc/RNA4-WEHZ] (situating the ongoing "diversity" movement in law schools within a tradition of resistance to racial subordination). For examples of the scholarship going back more than twenty-five years, see Ian Haney-Lopez, Community Ties, Race and Faculty Hiring: The Case for Professors Who Don't Think White, 1 RECONSTRUCTION 46 (1991), available at https://www.law.berkeley.edu/php-programs/faculty/facultyPubsPDF.php?facID=301\&pubID=26

[https://perma.cc/5BXG-Z3Y7]; Charles R. Lawrence III, Minority Hiring in AALS Law Schools: The Need for Voluntary Quotas, 20 U.S.F. L. REV. 429 (1986).

2. See, e.g., Johnson, One Dean's Perspective, supra note 1, at 1557-1563 (summarizing the benefits of faculty diversity to legal scholarship and teaching). A diverse faculty can help minority and female students feel more comfortable in the law school environment and offer them role models they can emulate. See Meera E. Deo, Maria Woodruff, \& Rican Vue, Paint by Number? How the Race and Gender of Law School Faculty Affect the First-Year Curriculum, 29 CHICANO-LATINO L. REV. 1, 9-10 (2010) (referencing studies concluding that the absence of a diverse faculty can lead to feelings of isolation among female students and students of color). See also Johnson, One Dean's Perspective, supra note 1, at 1557 ("[L]aw students want and need role models. This is especially the case for women and minority students, two groups that historically have been systematically excluded from law schools and the legal profession in the United States."). But see Anita L. Allen, On Being a Role Model, 6 BERKELEY WOMEN'S L. J. 22 (1990-91) (arguing that while diverse faculty have an important role to play in educating diverse students as "templates, symbols, and nurturers," overemphasizing "the role model argument" may reflect or reinforce biases by suggesting that diverse candidates do not deserve to be hired on the basis of their scholarly qualifications, by encouraging heightened expectations or requirements of diverse faculty, or by subtly undervaluing the other contributions and qualifications of excellent candidates who happen to be diverse). Faculty diversity also helps to instill an appreciation for diversity in the next generation of lawyers and leaders. See Carson, supra note 1, at 4-6 (noting the benefits AfricanAmerican faculty members can have on law schools and society writ large); Deo, Woodruff, \& Vue, supra at 36-37 (showing that women faculty and faculty of color are more likely to engage in diversity discussions in the classroom). Additionally, studies have shown that exposing students to women faculty and faculty of color breaks down stereotypical gender beliefs and prejudiced attitudes. Chris 
supports the benefits of diversity to organizations, showing that "[d]iverse teams and companies produce better results and higher revenue and profit." 3 Indeed, the bylaws of the American Association of Law Schools (AALS) identify diversityalong with academic freedom and excellence in teaching and research - as a core value. ${ }^{4}$ The AALS bylaws require member schools to demonstrate their commitment to a diverse faculty, ${ }^{5}$ and the outgoing and incoming presidents of AALS have just launched a two-year focus on diversity. ${ }^{6}$

A recent law review article argues that the diversifying task is done:7 "Now that the important work of race and gender integration has succeeded on law school faculties - with the traditional affirmative action groups now matching or exceeding their percentages in the broader lawyer population-the next step should be to desegregate law schools politically." 8 We are less convinced that law schools should be content with racial and gender underrepresentation that mirrors the underrepresentation in the broader legal profession. Achieving true parity in all faculty ranks remains important to transforming law schools into truly inclusive and egalitarian communities. ${ }^{9}$

Chambers Goodman \& Sarah E. Redfield, A Teacher Who Looks Like Me, 27 J. OF CIV. RTS. \& ECON. DEV. 105, 122 (2013). For information on additional benefits of a diverse faculty, see Goodman \& Redfield, supra at 117-18 (arguing for greater ethnic diversity among law school faculty) and Johnson, One Dean's Perspective, supra note 1.

3. See Sheryl Sandberg, Women Are Leaning In - but They Face Pushback, WALL ST. J. Sept. 27, 2016, https://www.wsj.com/articles/sheryl-sandberg-women-are-leaning-inbut-they-face-pushback-

1474963980 [https://perma.cc/VN64-ZX2K]. See also McKinsey \& Co., Women in the Workplace 2016, 7-8 (2016) (noting that while companies' commitment to gender diversity is high, they are not delivering results in terms of promoting women to positions of power - especially not CEOs).

4. Bylaws of the Association of American Law Schools, Inc., Ass'n of Am. Law Schs., (amended through Jan. 2016), https://www.aals.org/about/handbook/bylaws/ [https://perma.cc/LG7D-5P9A] ("The purpose of the [AALS] is the improvement of the legal profession through legal education - to uphold and advance excellence in legal education by promoting the core values of excellence in teaching and scholarship, academic freedom, and diversity, including diversity of backgrounds and viewpoints, while seeking to foster justice, and to serve our many communities-local, national, and international.").

5. See id. (stating that the AALS expects its member schools to value "diverse faculty hired, promoted, and retained based on meeting and supporting high standards of teaching and scholarship and in accordance with principles of nondiscrimination").

6. Call for Papers: AALS President's Program on Diversity, Ass'n of Am. Law Schs., https://www.aals.org/wp-content/uploads/2016/07/AALS-Presidential-Program-on-Diversity-Call-

for-Papers.pdf [https://perma.cc/U8C3-UTT4].

7. See, e.g., James Lindgren, Measuring Diversity: Law Faculties in 1997 and 2013, 39 HARVARD J. L. PUB. POL'Y 89 (offering a statistically-supported argument that discrimination against women and people of color is no longer as significant in law schools as discrimination against white Christian men).

8. Id. at 151.

9. Additionally, achieving a degree of diversity that reflects American society as a whole is important so that female and minority faculty are not viewed as tokens. Goodman \& Redfield, supra note 2 , at 118 . Treating faculty as tokens has a negative impact on diverse students whose token status is then also magnified-making the student feel like a member of the "out group." Id. at 125-26. Underrepresentation of women and minorities also results in these groups performing a disproportionate share of service work. See, e.g., Devon W. Carbado \& Mitu Gulati, Tenure, 53 J. LEGAL EDUC. 157, 171 (2003) ("A second complication is that the pressure minority candidates experience to take on service work is part of a more general pressure minorities feel to demonstrate institutional fit."); 
Although progress has been made over time, ${ }^{10}$ law schools still have a substantial distance to travel. The United States population is $51 \%$ female and $38 \%$ minority $\cdot{ }^{11}$ Representation of women and minority faculty comes closest to these figures at the entry level, but falls off higher up the faculty ladder. Women comprise $48 \%$ of tenure-track law faculty, but only $33 \%$ of tenured faculty, and $29 \%$ of law school deans. ${ }^{12}$ Ethnic minorities comprise $30 \%$ of tenure-track law faculty, but only $17 \%$ of tenured faculty and $21 \%$ of law school deans. ${ }^{13}$ A similar "pyramid problem" pattern prevails in academia generally. ${ }^{14}$

Unfortunately, it cannot be assumed that the upper-level figures will eventually "catch up" to the entry-level rates. A statistical analysis of 324 tenuretrack law faculty hired in 1996-97 found significant gender and ethnic disparities in the rates at which new hires persisted in academia and achieved tenure: $77 \%$ for non-minority men, $65 \%$ for non-minority women, $52 \%$ for minority women, and $42 \%$ for minority men. ${ }^{15}$ Law schools are still not hiring diverse faculty members

Paula A. Monopoli, Gender and the Crisis in Legal Education: Remaking the Academy in Our Image, 2012 MICH. ST. L. REV. 1745, 1770 ("“'Women pick up a disproportionate share of the 'housework' portion of such governance work.").

10. Among tenured faculty, the percentage of minority professors increased from $10 \%$ in $1998-99$ to $14 \%$ in 2005-06. AALS 2005-06 report, Table 2B (Year 2005-06), ASSOCIATION OF AMERICAN LAW SCHOOLS STATISTICAL REPORT ON LAW SCHOOL FACULTY AND CANDIDATES FOR LAW FACULTY POSITIONS - PRELIMINARY TABLES (2005-2006), Table 2B Seven-Year Comparison: Minority Faculty in Directory of Law Teachers. During the same time period, female professors increased from $20 \%$ to $26 \%$. Id. at Table 2A Seven-Year Comparison: Women Faculty in Directory of Law Teachers.

11. U.S. CENSUS BUREAU, U.S. DEP'T OF COMMERCE, QUICKFACTS, available at http://www.census.gov/quickfacts/table/PST045215/00 [https://perma.cc/EU5L-TK3S] (July 1 estimate).

12. The most recent available data are published by the American Bar Association (ABA), based on law schools reports submitted in 2013. Data from the 2013 Annual Questionnaire, ABA Approved Law School Staff and Faculty Members, Gender and Ethnicity: Fall 2013, AM. BAR Ass'N, available at http://www.americanbar.org/content/dam/aba/administrative/legal_education_and_admissions_to_t he_bar/statistics/2013_law_school_staff_gender_ethnicity.xlsx [https://perma.cc/F8H6-5WWE]. There were 5,398 tenured full-time teaching faculty, of whom 3,632 (67.3\%) were male and 1,766 (32.7\%) were female. There were also 1,509 tenure-track full-time teaching faculty, of whom 778 (51.6\%) were male and $731(48.4 \%)$ were female. Id. Among deans, there were 144 men and 58 women. Id.

13. Id. Within the ABA data, the "Total Minorities" category includes Hispanics, American Indian, Asian American, African American, Native Hawaiian Pacific Islander, and Two or More Races, but excludes Non Resident Aliens. Of the $(1,509)$ tenure-track faculty, there were 208 minority men and 252 minority women, for a total of $30.5 \%$ of the tenured full-time teaching faculty. Of the 5,398 tenured full-time teaching faculty, there were 508 minority men and 399 minority women, for a total of $16.8 \%$ of the tenured full-time teaching faculty. Of 202 law school deans, there were 25 minority men and 17 minority women, for a total of $20.8 \%$ of law school deans.

14. Women constitute $52 \%$ of non-tenure-track faculty, $41 \%$ of tenure-track faculty, and $26 \%$ of tenured faculty at doctoral universities, according to 2005-06 AAUP data. Martha S. West \& John W. Curtis, AAUP Faculty Gender Equity Indicators 2006, AM. ASs'N OF UNIV. PROFESSORS, available at https://www.aaup.org/NR/rdonlyres/63396944-44BE-4ABA-9815-

5792D93856F1/0/AAUPGenderEquityIndicators2006.pdf [https://perma.cc/9SZW-F89S] See also Mary Ann Mason, The Pyramid Problem, CHRONICle OF HigHeR EDUC., Mar. 9, 2011, http://www.chronicle.com/article/The-Pyramid-Problem/126614/ [https://perma.cc/3T26-7U2G].

15. Richard A. White, IndianA UniVERSity RePORT ON THE PROMOTION, RETENTION, AND TENURING OF LAW SCHOOL FACULTY: COMPARING FACULTY HIRED IN 1990 AND 1991 TO FACULTY HIRED IN 1996 AND 1997 13-14 (2004). 
in sufficient numbers to achieve parity, and the hiring gap is worsened by significant inequalities in promotion and tenure.

Improving faculty diversity may be more challenging in the current environment due to declining rates of student enrollment and faculty hiring freezes at many schools. ${ }^{16}$ However, this context makes it more important than ever to retain, develop, and promote diverse faculty. Yet, hiring diverse faculty members does not necessarily ensure that they are retained and promoted, ${ }^{17}$ and studies recognize that early-career mentoring helps improve the odds of retention. ${ }^{18}$ Making additional investments in already-hired law faculty also represents a particularly cost-effective diversity strategy.

This Article not only argues that law schools should make more systematic use of early career mentoring to promote faculty diversity, but also offers a costeffective, replicable model for doing so. Importantly, the mentoring program described here was designed by and for diverse early-career faculty, informed by the scientific literature on mentoring and adapted to the specific context of legal academia.

Most mentoring programs within law schools follow a standard model that assigns a protégé to one or more designated mentors within the school. Our program flips that model on its head, providing diverse early-career faculty members with training and resources to cultivate their own team of informal mentors. This reflects a finding within the mentoring literature that informal mentorship may be more effective than formal mentorship. A second unique feature of our mentorship program is the incorporation of both quantitative and qualitative techniques to evaluate its effectiveness. This Article presents the resulting data, allowing readers to judge for themselves the program's effectiveness, and providing insight into how and why mentorship can improve faculty outcomes.

Part I introduces the relevance of mentoring for enhancing faculty diversity. Part II draws upon the literature on mentoring within law faculties more broadly and explains the special concerns of early-career legal scholars that informed the program design. Part III describes the program model in sufficient detail to allow for its replication, including the evaluation methods. Part IV presents the results after the program's first year, drawing on both quantitative measures and participant narratives. Part V reflects on the potential for programs like this to contribute to broader change in the legal academy. For readers who would like to replicate or adapt this program at their own law schools, sample assessment forms are provided as appendices, as well as the grant proposal.

16. Meera E. Deo, Looking Forward to Diversity in Legal Academia, 29 BERKELEY J. GENDER L. \& JUSTICE 354, 354, 358 (2014).

17. WHITE, supra note 15, at 10-11; Ray K. Haynes, An Exploration and Assessment of Mentoring within the American Law Professoriate 724 (2006) (citing the AALS Statistical Report on Law School Faculty and Candidates for Law Faculty Positions 2000-2001).

18. See, e.g., Kelley Y. Testy, Best Practices for Hiring and Retaining a Diverse Law Faculty, 96 IowA L. REV. 1707, 1714-15 (2011) (stating that retaining faculty of color requires effort because such faculty members often suffer burdens not imposed on other faculty, including the burden of serving as the diversity representative on committees and other assignments); Ray K. Haynes \& Joseph M. Petrosko, An Investigation of Mentoring and Socialization Among Law Faculty, 17 MENTORING AND TUTORING: PARTNERSHIP IN LEARNING 41, 49 (2009). 


\section{Mentoring IN THE LeGAL ACADEMY}

The benefits of professional mentoring are numerous. Mentors provide protégés with both career and psychosocial support. ${ }^{19}$ According to an analysis of empirical literature, individuals who have been mentored report higher compensation, more promotions, greater career satisfaction, commitment, and optimism that they will advance further. ${ }^{20}$ For academics, professional mentoring has importance not only in the gatekeeping stages of landing the first job and surviving tenure review, but also in the ongoing process of pursuing excellence as a scholar and colleague, negotiating lateral moves, and advancing to a chaired position or deanship.

The literature on mentoring draws a distinction between formal and informal mentoring. "Formal" mentoring is more artificially structured and takes place in a setting where the mentor and mentee explicitly agree to undertake a mentoring relationship with specific goals and boundaries.

Mentoring can also take place informally, without an explicit agreement. A senior faculty member provides informal mentoring when she takes an interest in a young scholar, encourages her, offers feedback on her scholarship, provides her with professional opportunities, or makes introductions to others in the field. When a junior faculty member approaches a respected colleague to seek advice or assistance, she is initiating informal mentoring.

Informal mentoring remains the predominant mode in which junior faculty members are socialized to the expectations and methods of legal research and collegiality. In a 2009 study, only $23 \%$ of law faculty reported receiving formal mentoring, while $75 \%$ reported receiving informal mentoring. This might seem to call for greater emphasis on expanding formal mentoring. However, law faculty protégés are substantially more likely to characterize the mentoring they received as effective when it was informal (81\%) rather than formal $(56 \%))^{21}$ This mirrors a broader trend documented in the mentoring literature: mentees receiving informal mentoring report better satisfaction and outcomes than those receiving formal mentoring. ${ }^{22}$ Fortunately, these two forms of mentoring are not mutually exclusive, and a combination of formal and informal mentoring approaches is likely to be most effective. ${ }^{23}$

19. KATHY E. KRAM, MENTORING AT WORK: DEVELOPMENTAL RELATIONSHIPS IN ORGANIZATIONAL LIFE 5 (Scott, Foresman and Co. 1985). See also Darlene F. Zellers et al., Faculty Mentoring Programs: Reenvisioning Rather than Reinventing the Wheel, 78 REV. OF EDUC. RES. 552, 557-58 (2008) (listing the many benefits of mentoring).

20. See Tammy D. Allen et al., Career Benefits Associated with Mentoring for Protégés: A MetaAnalysis, 89 J. Applied Psychol. 127, 130 (2004). See also Neil Hamilton \& Lisa Montpetit Brabbit, Fostering Professionalism Through Mentoring, 57 J. LEGAL EDUC. 102, 107-08 (2007) (discussing the career mentoring function and psychosocial mentoring in detail).

21. Id.

22. Belle Rose Ragins \& John L. Cotton, Mentor Functions and Outcomes: A Comparison of Men and Women in Formal and Informal Mentoring Relationships, 84 J. OF APPLIED PsYCHOL. 529, 543 (1999).

23. But see Peg Boyle \& Bob Boice, Systematic Mentoring for New Faculty Teachers and Graduate Teaching Assistants, 22 INNOVATIVE HIGHER EDUC. 157, 159 (1998) (noting that it is overly "optimistic" to assume that new faculty will find spontaneous support, as well as warning that a laissez-faire approach has unfavorable results). 
Unfortunately, diverse faculty are at a disadvantage when it comes to mentoring. Studies show that women and minorities are less likely than individuals in majority groups to spontaneously develop informal mentoring relationships. ${ }^{24}$ According to Haynes, "[an] injurious consequence of the lack of formal mentoring programs is the likelihood that women and people of color [are] intentionally or unintentionally excluded from these informal mentoring relationships because they are demographically different from law faculty mentors." 25 Formal mentoring programs-whether open to everyone or specifically targeted at underrepresented groups-have been identified as important to achieving diversity goals in a broad range of contexts. ${ }^{26}$ While formal mentoring programs have the advantage that diverse faculty are more likely to participate in them, the data suggest that informal mentoring may be more effective. ${ }^{27}$ Thus, a key challenge in the design of mentoring initiatives for diverse faculty is how to leverage the strengths of both formal and informal mentoring.

The legal academy also presents unique challenges for ensuring that earlycareer faculty are adequately mentored as scholars. Because law faculty members are generally not required to complete a PhD program, ${ }^{28}$ they do not have the advantage of the scholarly mentoring foundation that such programs provide. Many law schools discourage co-authorship prior to tenure, ${ }^{29}$ depriving junior law faculty of yet another prime opportunity for informal mentoring. Law departments also tend to seek a diversity of research interests in hiring, in order to offer the broadest variety of courses and expert faculty to students. For this reason, research collaborations in the law most commonly take place between faculty from two or more different law schools. Even if scholarly mentoring is possible within the law school, it may create conflicts of interest at the time of the tenure vote..$^{30}$ Thus, the organic opportunities for mentoring through research collaboration that would be found within many other university departments tend to be lacking in the law.

24. See Zellers et al., supra note 19, at 553 (citing studies in the corporate and academic world suggesting that women and minorities face "significant barriers in developing informal workplace mentoring relationships"); id. at 558-59 (summarizing literature on the "cloning" phenomenon in academic and business settings, whereby informal mentors disproportionately cultivate protégés who remind them of themselves).

25. Haynes \& Petrosko, supra note 18, at 49.

26. See, e.g., Deborah A. Olson \& Deborrah Jackson, Expanding Leadership Diversity Through Formal Mentoring Programs, 3 J. OF LEADERSHIP STUD. 47 (2009).

27. See supra note 22 and accompanying text. But see Hamilton \& Brabbit, supra note 20, at 121 ("The early research suggesting that informal mentoring relationships provide more benefit to protégés than formal programs does not control for characteristics of formal programs, and so the conclusion that informal relationships provide more benefit seems premature.").

28. See, e.g., Brian Leiter, Paths to Law Teaching, The University of Chicago Law School, https://perma.cc/M37W-4VLB (last updated Dec. 2015).

29. Several factors contribute to this phenomenon, including difficulties assigning credit among authors and the effect on tenure committees' deliberations. Tom Ginsburg \& Thomas J. Miles, Empiricism and the Rising Incidence of Coauthorship in Law, 2011 U. ILL. L. REV. 1785, 1824 (2011).

30. See, e.g., Daniel Keating, A Comprehensive Approach to Orientation and Mentoring for New Faculty, 46 J. LEGAL EDUC. 59, 63 (1996) (noting that offering an internal faculty mentor to a junior faculty member may create a concern about conflicts regarding the eventual tenure vote). 
To realize these opportunities, pre-tenure law faculty must actively engage research mentors and collaborators within their fields. The standard law school mentoring program - matching a junior faculty member with a senior member of the same faculty-generally does not achieve this. It is crucial that legal scholars develop mentors "beyond the building" - at other law schools, in other departments, or in related fields of practice.

Additionally, the new mentoring paradigm in the literature is not focused on having just one mentor, but rather a network of mentors that complement each other and fulfill different functions. ${ }^{31}$ "The notion of a single experienced faculty member being able to play the all-inclusive role of mentor to a protégé is probably wishful thinking." 32 Alternative models-including peer mentoring, collective mentoring, and multiple mentoring - have a particularly important role to play in supporting diverse early-career faculty. ${ }^{33}$ We consider the multiple mentoring model - in which the mentee takes the initiative to cultivate a network of mentors fulfilling different needs - particularly appropriate for early-career legal scholars.

Some early-career faculty members may be at a disadvantage in developing these networks of mentors because of their more isolated geographical location or more limited institutional resources. Scholars in coastal corridors can travel at little expense to nearby law schools to present research, network with colleagues, and cultivate mentors and collaborators. Scholars based in other parts of the country typically require a flight and hotel to realize the same benefit. As a legal scholar rises in reputation, she will receive more and more invitations on an expense-paid basis. But in the early-career stage, when it is most important to establish a network of mentors, law faculty are more likely to be dependent on their own institution's funding.

In sum, professional mentoring - particularly around research - is important to faculty retention and advancement. Relying on spontaneous mentoring, however, tends to disadvantage diverse faculty. The introduction of formal mentoring programs pairing junior and senior faculty members within an institution represents an improvement, but also has limits. The literature suggests that junior faculty members will realize the greatest benefit from having a network of informal mentors. Because of the unique characteristics of legal scholarship, mentoring around research, in particular, requires reaching beyond one's own institution. Depending on the geographic location of a particular school, this may require allocating financial resources for junior faculty members to travel to where their potential mentors are located.

31. See Zellers et al., supra note 19, at 563 ("The new mentoring paradigm is epitomized by multiple mentoring relationships, which have been described in the literature as constellations or mosaics of supportive relationships. The concept of multiple mentoring encourages individuals to draw support from a diverse set or team of mentors.") (citations omitted).

32. William G. Tierney \& Estela Mara Bensimon, Promotion AND TENure: COMMUNity AND SOCIALIZATION IN ACADEME 52 (1996).

33. Naomi C. Chesler \& Mark A. Chesler, Gender-Informed Mentoring Strategies for Women Engineering Scholars: On Establishing a Caring Community, 91 J. OF ENGINEERING EDUC. 49, 51-52 (2002). 


\section{Designing A RePLiCABle Model}

The impetus for developing this mentoring program at Indiana University Robert H. McKinney School of Law was a campus-wide initiative by the Office for Academic Affairs. ${ }^{34}$ The campus initiative offered matching funding for departments proposing significant new mentoring programs to support faculty retention and promotion. Departments were strongly encouraged to focus their proposed initiatives on populations that would help to advance the diversity goals of the campus. Since our junior faculty at the time happened to comprise six women, including one woman of color, it was natural to take the junior faculty as our focus. ${ }^{35}$ In proposing the program and securing institutional buy-in, we emphasized the benefits for faculty diversity, as well as broader goals of promoting research excellence and faculty retention. We noted that if our proposed program achieved its goals and all faculty members participating in the mentoring program were retained and tenured, the law school's tenured faculty would go from $30 \%$ female to nearly $40 \%$ female. ${ }^{36}$ The proposal was ultimately approved and fully funded, under the name Mentoring Untenured Scholars for Clinical and Legal Excellence (MUSCLE).

In designing the program, we began by speaking informally to both junior and senior law school faculty to identify challenges related to mentoring on our campus. We found that our junior faculty were very satisfied with the mentorship available to them in the areas of teaching and institutional citizenship. Because of the universal nature of these responsibilities, this type of mentoring is easy to find within the law school. Senior colleagues at our school tend to be very generous with their time when questions or issues arise in these areas. Student evaluation data also bore out that there was little to no need for support in the field of teaching, as this population was already performing above the institutional average in the classroom. ${ }^{37}$ It was during this process, however, that we identified the specific need for research mentorship. Both junior and senior faculty at IU McKinney noted research-focused mentoring as the top priority. Like most American law schools, ours has a strong expectation that non-clinical faculty should go up for tenure and promotion based on excellence in research. The law school's pre-tenure research faculty members also have a strong motivation to achieve this excellence, not merely for the purposes of tenure and promotion, but also for the more fundamental purposes of advancing their research agendas,

34. See Gail Williamson ET Al., IUPUi OfFice Of THE EXeCUtive Vice CHANCELlor White PAPER ON FACulty TAlent Development EFFort "Mentoring ACADEMY" (Apr. 22, 2014), available at https://perma.cc/QR24-GSSC.

35. No deliberate law school policy required hiring this female faculty. The reason that it "happened" to be all female is that the last male tenure-track faculty member had been tenured, recent male faculty hires were more senior laterals, and one junior male professor departed the faculty for another institution. Three of the six MUSCLE participants are authors of this paper.

36. Several female faculty had retired in recent years, decreasing the tenured female faculty to $30 \%$.

37. LEA SHAVER ET AL., MUSCLE MENTORING UNTENURED SCHOlARS FOR CLINICAL AND LEGAL SCHOLARSHIP EXCELLENCE (2014), Robert H. McKinney School of Law proposal, as funded, available at https://perma.cc/AFF7-RZA3. 
contributing to the profession and society as a whole, and fully enjoying their calling as scholars.

Because of factors specific to the structure of legal research, ${ }^{38}$ we came to believe that it was particularly important for research mentoring to involve a network of mentors and collaborators "beyond the building." Because of our Midwestern location, building these relationships requires significant travel. Although our institution provides all faculty with a moderate travel budget, there is currently no ability to seek additional travel funds from the dean based on special needs or opportunities. Early-career faculty noted that they are particularly dependent on institutional funding because they have not yet built the reputations and networks that lead to paid invitations. Yet early-career faculty at our institution did not enjoy any priority in the allocation of institutional travel funds. We therefore identified enhanced travel funding as a critical component of the program. Based on the Office of Academic Affairs budget guidelines, departmental matching requirements, and the number of faculty members in our target population, we arrived at the figure of $\$ 1,500$ of travel funds per person per year necessary to accomplish the goals of the program. Participants were told they could use these funds for travel to a conference with a significant mentorship component, or for a trip specifically focused on networking and mentoring unrelated to a conference.

If additional travel funding was the "dough" of our new mentoring initiative, the "yeast" was brief programming to sensitize participants to the importance of mentoring for their academic careers. The mentoring literature suggested that informal mentoring relationships may be most effective. We therefore devised a hybrid program with few formal aspects, which emphasized the need for participants to proactively activate and develop an informal mentoring network of their own that was consistent with the "multiple mentoring" model. Accordingly, participants attended a single hour-long discussion session, which focused on the "why and how" of developing their own network of informal mentors. Participants were encouraged to share their experiences with one another during the program, and were expected to write a brief self-evaluation memo at the end of the year. Ultimately, each participant spent many hours engaged in mentoring interactions, but these experiences were structured by the participants themselves, not by the program.

Perhaps the most important features of our program were the assessment components. Two different instruments were developed. Each participant prepared a short narrative self-report memo describing her participation in the program and what she accomplished. The self-reporting memos held participating faculty members accountable for setting their own mentoring goals, making mentorship development a priority, designing travel with mentorship in mind, and reflecting on their progress toward their mentorship goals. These were shared with law school leadership and among the participants. This had the benefit of further reinforcing the message about the importance of mentorship, and sharing strategies of how to most effectively use the funds. Participants also anonymously completed a survey that assessed their perceptions (on a one- to five-point scale) regarding measurable goals of the program. The quantitative instrument was

38. See id. at 5-6 (discussing "Methodology of Intervention"). 
administered at the program's beginning and at the end of its first year, permitting comparisons across time. Both the quantitative and qualitative assessments were designed to evaluate the program's effectiveness, identify avenues for year-onyear improvement, and provide evidence to make a case for continuing the program beyond the initial grant term. We reproduce these assessment instruments in the appendices.

\section{RESULTS AFTER THE FIRST YEAR}

To objectively assess the program's success in achieving its goals, two different measurement instruments were used. Both assessments suggest the program was successful in advancing mentoring of the participating faculty members.

\section{A. Quantitative Assessment Tool}

The data obtained from the (anonymous) quantitative instrument reveal positive progress toward all of the program's measurable goals, with many measures improving dramatically. Participants were asked to score on a five-point scale their responses to thirteen questions regarding measurable goals at the beginning of the MUSCLE program in 2015, and then again after the first year of the program in 2016.

Four measures showed at least one full point improvement on a five-point scale. Compared to a year ago, participants now feel substantially better informed about the mentoring resources available to them at their law school and the broader university campus. Participants also express much greater confidence that they know how to effectively cultivate a network of mentors to help them achieve excellence in research, and that they have the necessary resources to do so. Participants further reported substantially stronger relationships with their mentors after the intervention. These measures suggest that MUSCLE participants feel significantly more empowered to cultivate their own networks of research mentors - the core goal of the program.

Several additional measures showed at least one-half point improvement on the five-point scale. Among these, MUSCLE participants increasingly report that they consider mentoring "very" important to their success as a legal scholar. They also report regarding research that they are more frequently in contact with mentors both within the law school and beyond. Participants additionally report that they feel more prepared and motivated to serve as a mentor to others. These measures all suggest an attitudinal shift: MUSCLE participants have become more sensitive to the value of mentoring, which has paid dividends not only "beyond the building," but also within it.

Two measures from the survey instrument showed more limited improvement, of less than one-half point on the five-point scale. Included in these measures, MUSCLE participants report that they are somewhat more satisfied with the research-related mentorship they receive from outside the law school. They are only slightly more satisfied with the current progress of their research agenda. These "satisfaction" measures show the smallest improvement, perhaps because the MUSCLE program has also led participants to raise their expectations even higher. 
Table 1. Improvement in Mentorship Indicators After First Year of MUSCLE

\begin{tabular}{|l|c|}
\hline \multicolumn{1}{|c|}{ Survey Item } & $\begin{array}{c}\text { Average } \\
\text { point change on } \\
\text { five-point scale }\end{array}$ \\
\hline $\begin{array}{l}\text { How satisfied are you with the current progress of your } \\
\text { research agenda? }\end{array}$ & 0.1 \\
\hline $\begin{array}{l}\text { How satisfied are you with the research culture at McKinney } \\
\text { Law School? }\end{array}$ & 0.5 \\
\hline $\begin{array}{l}\text { How important do you consider mentoring to your success as a } \\
\text { legal scholar? }\end{array}$ & 0.5 \\
\hline $\begin{array}{l}\text { How satisfied are you with the research-related mentorship you } \\
\text { receive at McKinney? }\end{array}$ & 0.5 \\
\hline $\begin{array}{l}\text { How satisfied are you with research-related mentorship you } \\
\text { receive from outside sources? }\end{array}$ & 0.4 \\
\hline $\begin{array}{l}\text { How frequently are you in contact with mentors within } \\
\text { McKinney regarding research? }\end{array}$ & 0.5 \\
\hline $\begin{array}{l}\text { How frequently are you in contact with mentors outside the } \\
\text { law school regarding research? }\end{array}$ & 1.1 \\
\hline $\begin{array}{l}\text { How strong are your relationships with the mentors in your } \\
\text { network currently? }\end{array}$ & 1.0 \\
\hline $\begin{array}{l}\text { How well informed are you about mentoring resources } \\
\text { available at McKinney and IUPUI? }\end{array}$ & 0.7 \\
\hline $\begin{array}{l}\text { How confident are you that you know how to develop a } \\
\text { network of research mentors? }\end{array}$ & $\begin{array}{l}\text { fou } \\
\text { How confident are you that you have the resources necessary to } \\
\text { cultivate mentors? }\end{array}$ \\
\hline $\begin{array}{l}\text { How satisfied are you with the level of research travel funds } \\
\text { available to you this past year? }\end{array}$ & $\begin{array}{l}\text { How prepared and motivated are you to serve as a research } \\
\text { mentor to other legal scholars? }\end{array}$ \\
\hline
\end{tabular}

Quantitative improvements were observed along all of the program goals. Satisfaction is improving, the value placed upon mentoring has increased substantially, and participants' sense of empowerment to cultivate mentors has seen the greatest increase.

\section{B. Narrative Assessment Tool}

The individual narrative self-assessments reinforce the conclusion that the improvements in regard to cultivating mentors and the importance of mentoring are a direct result of MUSCLE. While we received responses identified by the 
resondent's name, we reproduce selected anonymized comments to demonstrate five emerging themes. ${ }^{39}$

\section{Different Methods of Incorporating Mentorship into Travel Plans}

Consistent with the program's focus on empowering participants to identify and meet their own mentoring needs, participants reported using the travel funding in diverse ways.

Most participants used at least part of the extra funding to attend conferences or workshops that they would ordinarily have had to skip.

I used a substantial amount of the MUSCLE funding to attend the ... [c]onference, which specifically targets [minority] law school faculty (although all are welcome) and aims to provide a supportive network across the academy. More importantly, the conference deliberately works to facilitate mentor-mentee relationships between tenured and untenured faculty members.

With the funding, I was able to take two trips, each of which involved a significant mentoring component. Each of these trips has had significant follow-up effects for my work and career, and without the funding, I most likely would have had to choose between the trips.

The workshop operated on a slim budget so participants had to fund their own airfare. But for MUSCLE, I would have declined the invitation. And I am so glad I went! Somewhat to my surprise, the workshop turned out to be an excellent opportunity for cultivating mentors. I was the most junior scholar in the room, in the company of four superstar scholars in my field.

Other participants used their funds to conduct a trip focused on spending one-on-one time with mentors in their field, unconnected to a conference or workshop:

Prior to the MUSCLE program, I did not have this luxury because I did not have the funding to take mentoring trips, yet it is so important-I now see-because it is quality one-on-one time that would not be possible in a more hectic context, such as a national conference. Furthermore, taking a specific mentoring trip puts mentoring on the agenda as a priority, and it results in quality mentoring because of this prominence on the agenda.

I appreciated having the additional funds to use for me, not just for presentation appearances. It was really nice to have several days to connect one-on-one with people that I really admire and respect.

The remaining $\$ 200$ was used for a one-night hotel stay [in a nearby state capital]. The primary purpose of the visit was to meet and engage with two very well-respected lobbyists who work with issues related to my research area. This was a fruitful visit both on the mentor front as well as the research sphere. They both gave me great advice about my research and suggested other avenues that I ought to explore. Their advice included not only suggestions concerning important additional legislation but also other helpful contacts. They explained to me the "politics" behind much of the legislation I was interested in, and also put me in touch with important bureaucrats.

39. We received consent from MUSCLE participants and Institutional Review Board approval to use these narratives in any publications regarding the mentoring program. As part of the approval, we agreed to report them anonymously and to remove any identifying information. 
Some trips combined both approaches: attending a conference and including an additional "mentoring day" with the extra funding.

I had been invited to participate in a workshop at [one university], with my flight and related expenses paid by the host institution. I used about $\$ 250$ of MUSCLE funds to cover a second night's hotel stay and a rental car, in order to add on a half-day visit to [a nearby university].

I booked a ticket allowing me to arrive early so that I could spend half a day meeting with faculty. I had never met most of these people before. I just emailed them three weeks in advance to say I would be in town and could I visit their office to seek some career advice as a young legal scholar. Everyone said yes.

Because the program gave protégées significant discretion over the use of their travel funds, each participant was able to put the resources to what she deemed the best use.

\section{Mentoring on Research and Other Topics}

Of the six participants in our program, the five tenure-track faculty will go up for tenure in research and the clinical professor will go up for long-term contract status in teaching. All of the participants reported focusing mentorship conversations on their research or clinical program design, and receiving valuable advice in these areas.

The narratives indicate that participants were able to obtain mentoring focused specifically on research, including advice on publishing a first book, reframing an article's argument, new issues within a field that should receive attention, scholarly blogging, and more. Mentoring conversations also extended to related topics such as pitfalls to avoid in going up for tenure and general career advice.

I used the bulk of the funding to attend a conference that attracts many scholars in my research area. It is also one that many junior scholars want to participate in because (1) it involves a competitive process for participation (double blind review of research abstracts) and (2) pairs participants with a discussant who is established in the same research field as the junior scholar. My discussant was an expert in my general area of research. She provided detailed comments on my paper and also gave me advice on avenues for publication. Indeed, she suggested that I could build on the draft article and propose a book project based on some of the ideas discussed in the draft. I also turned to her for additional comments on [a] grant application I submitted later. Another scholar in my area approached me after my presentation and has since provided me detailed comments on the draft article. I incorporated her fantastic comments.

Professor [so-and-so], an expert in [my field] commented on my most recent article. Her comments were invaluable and significantly contributed to an important doctrinal change in my piece. I continue to receive correspondence from this professor.

I reached out to friends as soon as I received [a nearby] invitation; they were able to put me on the schedule for a speaker series. I presented to an audience of about 30 law students and interdisciplinary scholars. I used the forum as an opportunity to broadly describe and reflect on the trajectory of my research during my path to tenure. During the discussion, I benefited from the perspectives and feedback of a diverse group of scholars.

[Professor such-and-such] is not in my field, but he has published many academic books that also reach a general audience. I wanted to get his advice on my own book project. I was 
surprised to learn that it actually is now acceptable (and common practice) to simultaneously send a book proposal to multiple university presses. He gave me great advice on how to identify presses worth applying to, and how to frame my proposal and enquiry email. [Another professor] gave me great substantive feedback on many angles of my book project, as well as advice about non-research activities (such as consulting) that would or would not be a good idea to take on after achieving tenure.

I spent [several days] of my trip working with [two people in my field] and learning more about what they do, how they do it, and how we might be able to partner together in the future.

The nature of these conversations ran the gamut from tenure to reading additional drafts of my paper to advice on drafting grants to the possibility of a research collaboration in the near future.

I had many conversations with [a practitioner in my field] regarding my research... She also connected me to a number of conferences in my research area in [the region] and outside of the legal academy that I have found useful to understanding the practical effects of legislation and programming [in this field]. She is now someone I consider a mentor and she continues to advise me on my research.

\section{New Opportunities as a Result of Mentoring Relationships}

Several participants reported that their mentoring outreach resulted in additional invitations or other professional opportunities, in addition to research and career advice.

The additional MUSCLE funds caused me to think about reaching out to my senior colleagues to see if they could seek out some opportunities for me to present my work. Basically, I told a couple of senior colleagues that I had some funds that would allow me to pay to travel to another law school and give a talk, so that the other law school did not have to pay for me to visit. One of my colleagues made some calls and was successful in arranging for me to present.

A scholar I met [on a funded trip] agreed to make efforts to reach out to her contacts so that I might interview them for my research.

I garnered two conference invitations from mentoring conversations, each of which I accepted and each of which I am certain will lead to more relationships and scholarly development.

Because I was involved in designing the MUSCLE program, I actually began cultivating my mentorship relationships more intentionally about a year ago. These efforts have already begun to pay off. I would estimate that as a direct result of more intentionally cultivating relationships with external mentors, I benefitted from at least $\$ 4000$ in travel funding and $\$ 7500$ in research support from other institutions.

Because many of the seeds planted during mentorship travel may take time to grow, this early analysis likely underestimates the follow-on opportunities that will ultimately come about as a result of investments in mentorship.

\section{An Attitudinal Shift: Appreciating and Prioritizing Mentorship}

Another theme that emerges from the narratives is that participants report a shift in attitudes toward mentoring. More than one participant reported that the very fact of having a program focused on mentoring encouraged prioritization of 
it. The funding and reporting held participants accountable. The program also required participants to consciously focus on mentoring and to reflect on its impact. The reflection process itself emerges as a significant component of the intervention, sensitizing participants to their own power to advance their careers by proactively seeking out mentoring.

The MUSCLE program support has made me really think about mentoring and made me feel that I have the additional resources to help me seek out opportunities to connect with senior scholars and other scholars in my field. Seeking out mentors is not easy work. But, this funding essentially forces me to get out there and ask for advice and input. I am at the beginning stages of "seeking out mentors." But, I feel that I am now on track. I am much more willing than I was before to reach out to people and ask for help and advice - and to ask them to read my work and comment on it. I hope to get even better next year at seeking out and building on my existing mentoring relationships.

The MUSCLE program influenced the way I view mentoring as part of my professional development by virtue of allocating funds specifically geared toward establishing mentoring relationship. This demonstrates a commitment by the University to mentoring as well as signals the importance of professional mentor relationships. I never thought about the importance of mentoring until the MUSCLE program. Prior to MUSCLE, I had two people that I consider mentors and I did not think to broaden my mentor circle until MUSCLE. With the MUSCLE funds, I was very deliberate in choosing where to go and the mentor objectives to be achieved. I am happy to report back that my experiences were wonderful. I now have at least eight people that I consider mentors and feel free to consult with.

MUSCLE opened my eyes to something that should have been obvious but was not: the importance of seeking out professional advice and tending to personal relationships. A year ago I would have said I had one mentor. Now, I would say there are several dozen people on my mentoring team. I have learned that cultivating mentoring relationships is actually quite emotionally fulfilling both for me and for my intended mentor, that it is surprisingly easy for me to do, and that people are actually very willing and happy to do it when they see that you appreciate it. I was surprised to see in my own life just how powerful the payoff of mentorship turned out to be. I feel this has had an enormous positive impact on my research and broader professional development.

The MUSCLE program has made apparent to me how immediate and influential the effects of mentoring can be. I actually was not aware of the direct and significant career benefits I had received from the mentoring component of the conferences I attended until working on this self-assessment.

The biggest impact that my participation in the MUSCLE program had was on the way I now approach mentoring - as worthy of a trip and time in itself.

\section{Additional Themes}

The program did not require participants to commit to investing a minimum number of hours in mentorship conversations. Nor did the assessment techniques directly ask how much time participants actually spent in mentorship activities. The narratives, however, make clear that participants ultimately chose to spend many hours on these activities. An improvement in the assessment documents for the future would be to ask participants to estimate the number of hours they spent in certain categories of mentorship activities. 
Some participants also mentioned that they became more aware of their own role as potential mentors to scholars more junior than they are, and that they had invested additional time in these activities as a result of participation. Future iterations of assessment instruments might ask questions to specifically get at this dynamic, considering its potential benefits for the participants' colleagues and students within their own institution.

\section{CONCLUSION}

Recognizing diversity as a core value in legal education, law schools continue to pursue the elusive goal of faculty parity. Mentoring diverse faculty for retention and promotion represents an important strategy, particularly in times of slow hiring. Mentoring is widely acknowledged to be important in career advancement, yet can be lacking for female and minority professors, which can contribute to disparities in retention and advancement. Empowering early-career faculty to proactively cultivate research mentors should be recognized as an important strategy to achieve law schools' diversity goals.

The mentoring program described in this Article has been in place for only one year. The results described here are necessarily preliminary, and limited to one institution. Yet both the quantitative and qualitative data demonstrate positive effects. Participants report taking mentorship more seriously, are investing significant time in mentorship, express greater satisfaction in the mentoring available to them, and are receiving advice and opportunities that they consider to be valuable to their academic careers.

In designing mentoring interventions, law schools should keep in mind the need to blend the advantages of formal and informal mentoring. Relying on organic or spontaneous mentoring alone is likely to disadvantage diverse faculty members and perpetuate gender and racial disparities in retention and promotion. Ultimately, however, the most effective mentoring occurs informally, not as part of an official "match." We believe that the best of both worlds can be found in a program that targets diverse faculty members, emphasizes the importance of mentoring, provides financial resources and moral support to empower them, and holds them accountable to cultivate their own network of informal mentors.

The particular approach described here may not be ideal for all law schools. Indeed, it is important to emphasize that this mentoring initiative was designed by listening and responding to faculty preferences at our institution. The points we consider most central to its success were encouraging early-career faculty members to take initiative in cultivating their own network of professional mentors, providing appropriate financial resources to facilitate these efforts, and using a narrative reporting obligation to hold participants accountable and facilitate reflective learning. We think that travel funding not only facilitated relationship-building with geographically distant mentors, but also represented an important hook to recruit participants who might not already be convinced of the value of mentoring for their academic careers. While the amount of additional travel support could be varied, we would caution against attempting to replicate this program without it.

Our hope is that this detailed model can serve as a starting point for discussions regarding effective efforts to bolster mentoring as a diversity strategy. We also hope that we can save future program champions significant time by 
providing ready-made resources with which to work. In the appendices, we include templates for our assessment tools and a logic model mapping out the program, which can be used during the planning and implementation of a similar program. These help facilitate the reflective self-assessment that we found to be an important part of the program, as well as evidence collection to demonstrate the impact of a trial program. Many campuses have funds available to support department-level mentoring initiatives; we have made our grant proposal available as a model. ${ }^{40}$

The model described here can also be implemented without establishing a formal program. Early-career faculty members who are persuaded of the potential benefits can adopt the multiple mentoring model and begin to cultivate their own networks immediately. If they think they need additional financial resources to support travel for this purpose, they can approach their dean directly and propose a pilot program, sharing the literature on mentorship and promising to hold themselves accountable for setting and achieving mentorship goals by reporting on their use of the mentorship funds on an annual or semiannual basis. Deans can also implement this approach themselves by offering small bonus funds to their most junior faculty members.

Although our experiment focused on enhancing gender diversity, the model can work to promote any dimension of diversity, including racial, socioeconomic, or political diversity. ${ }^{41}$ The model can also be adapted to target scholars at different points in their careers. For example, another program might focus on mid-career legal academics, with the goal of increasing diversity among future deans. Schools that send many graduates to legal academia can also adapt the program to serve current law students, as a way of improving the diversity pipeline. In this way, diversity mentorship can help to address the diversity gap in hiring, as well as in advancement.

40. See supra note 37.

41. Cf., Johnson, One Dean's Perspective, supra note 1, at 1566 (emphasizing the importance of multiple "dimensions" of diversity, not just racial and gender diversity, for law school excellence). 


\section{APPENDIX A: QuANTITATIVE ASSESSMENT TOOL}

\section{MUSCLE ASSESSMENT}

Please complete and submit this assessment anonymously. Your answers will be aggregated with those of other participants. Thank you for your participation.

\begin{tabular}{|l|c|c|c|c|c|}
\hline $\begin{array}{l}\text { Please circle ONE number only } \\
\text { for each of the following statements. }\end{array}$ & $\begin{array}{c}\text { NOT } \\
\text { VERY }\end{array}$ & $\begin{array}{c}\text { SOME- } \\
\text { WHAT }\end{array}$ & VERY \\
\hline $\begin{array}{l}\text { How satisfied are you with the current } \\
\text { progress of your research agenda? }\end{array}$ & 1 & 2 & 3 & 4 & 5 \\
\hline $\begin{array}{l}\text { How satisfied are you with the research } \\
\text { culture at McKinney Law School? }\end{array}$ & 1 & 2 & 3 & 4 & 5 \\
\hline $\begin{array}{l}\text { How important do you consider mentoring to } \\
\text { your success as a legal scholar? }\end{array}$ & 1 & 2 & 3 & 4 & 5 \\
\hline $\begin{array}{l}\text { How satisfied are you with the research- } \\
\text { related mentorship you receive at McKinney? }\end{array}$ & 1 & 2 & 3 & 4 & 5 \\
\hline $\begin{array}{l}\text { How satisfied are you with research-related } \\
\text { mentorship you receive from outside sources? }\end{array}$ & 1 & 2 & 3 & 4 & 5 \\
\hline $\begin{array}{l}\text { How frequently are you in contact with } \\
\text { mentors within McKinney regarding research? }\end{array}$ & 1 & 2 & 3 & 4 & 5 \\
\hline $\begin{array}{l}\text { How frequently are you in contact with } \\
\text { mentors outside the law school regarding } \\
\text { research? }\end{array}$ & 1 & 2 & 3 & 4 & 5 \\
\hline $\begin{array}{l}\text { How strong are your relationships with the } \\
\text { mentors in your network currently? }\end{array}$ & 1 & 2 & 3 & 4 & 5 \\
\hline $\begin{array}{l}\text { How well informed are you about mentoring } \\
\text { resources available at McKinney and IUPUI? }\end{array}$ & 1 & 2 & 3 & 4 & 5 \\
\hline $\begin{array}{l}\text { How confident are you that you know how to } \\
\text { develop a network of research mentors? }\end{array}$ & 1 & 2 & 3 & 4 & 5 \\
\hline $\begin{array}{l}\text { How confident are you that you have the } \\
\text { resources necessary to cultivate mentors? }\end{array}$ & 1 & 2 & 3 & 4 & 5 \\
\hline $\begin{array}{l}\text { How satisfied are you with the level of } \\
\text { research travel funds available to you this past } \\
\text { year? }\end{array}$ & 1 & 2 & 3 & 4 & 5 \\
\hline $\begin{array}{l}\text { How prepared and motivated are you to serve } \\
\text { as a research mentor to other legal scholars? }\end{array}$ & 1 & 2 & 3 & 4 & 5 \\
\hline
\end{tabular}


APPENDIX B: NARRATIVE ASSESSMENT TOOL

\section{MUSCLE: Mentoring Untenured Scholars for Clinical and Legal Scholarship Excellence}

To: MUSCLE Participants

From: Research Committee

Date: Summer 2016

Re: Participant self-evaluation

Thank you for participating in the inaugural year of MUSCLE. As part of the administration of this program, we expect all participants to complete an annual narrative self-assessment of their participation. Together with the anonymously gathered quantitative data, these narratives will help us to assess the effectiveness of the program, and to find ways to further improve it. This evidence can also be helpful to the Dean when seeking additional funding to continue the program.

Toward that end, please prepare a 2-3 page memo explaining how you have utilized the resources provided by MUSCLE over the past year, and with what results. These memos should be returned to the chair of the research committee by email no later than [DATE]. You may find it helpful to address some or all of the following questions, although you should also feel free to go beyond these questions as well. No particular format is required.

- Explain which MUSCLE components (workshops, assessment tools, travel funding, mentor MVP nominations) you personally found most helpful this year.

- Please describe how you used your additional travel funds; where you went, who you met with, what topics your mentoring conversations covered, etc.

- What follow-up has occurred building on this travel? For example, phone conversations with mentors, future invitations, reading drafts, coauthorship, etc.

- How has the funded travel impacted your research? Have you received additional invitations or opportunities as a result of relationships built?

- How has participation in the MUSCLE program influenced the way that you view and approach mentoring as part of your professional development?

- In what ways has your mentoring network gotten stronger over the past year? What actions of your own do you attribute that to?

- What steps do you want to take in the next year to further strengthen and best utilize these mentoring relationships? How do you propose to spend your travel funds?

- Do you consider it important to continue the MUSCLE program in the future? Please explain why or why not. 
APPENDIX C: LOGIC MODEL

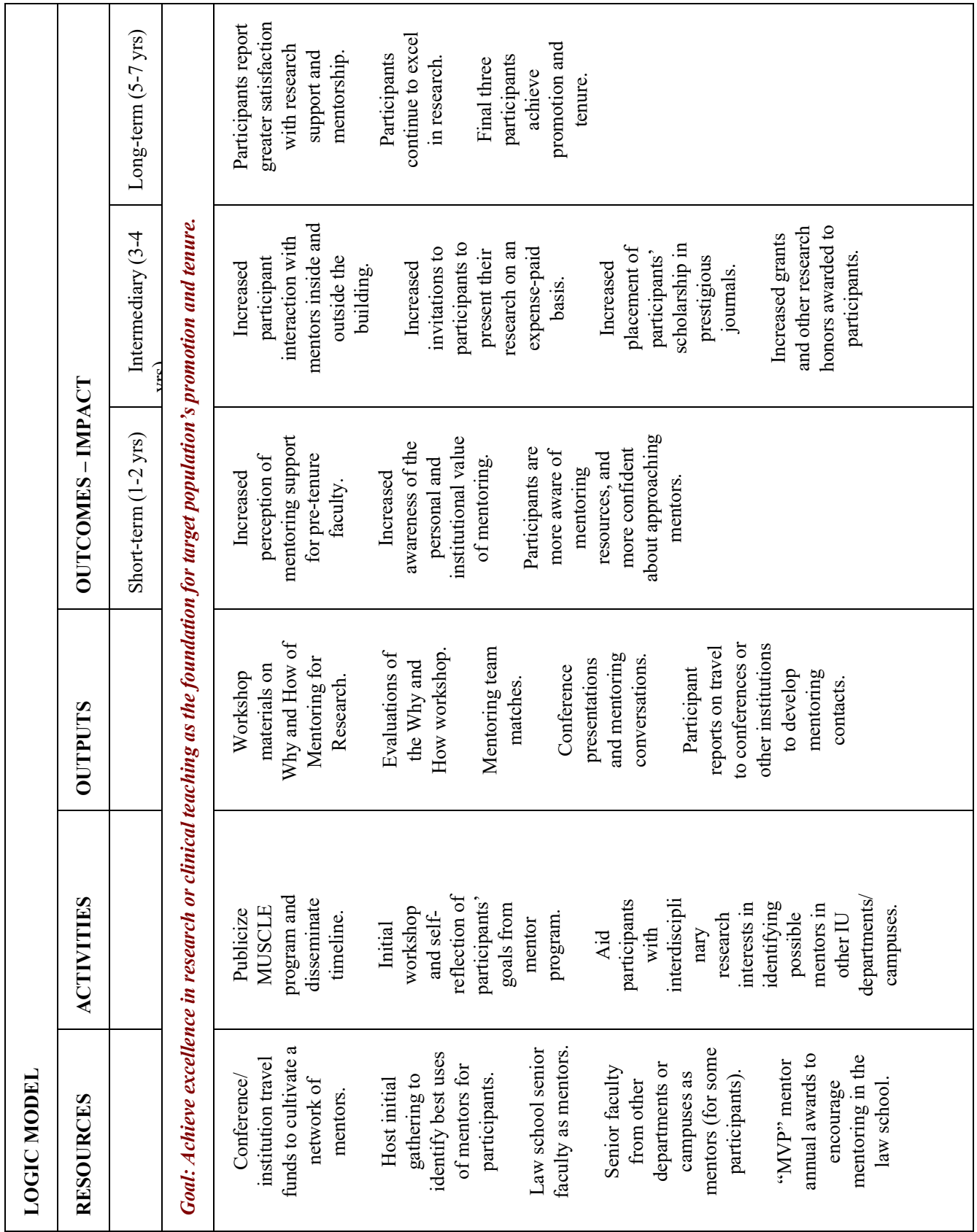




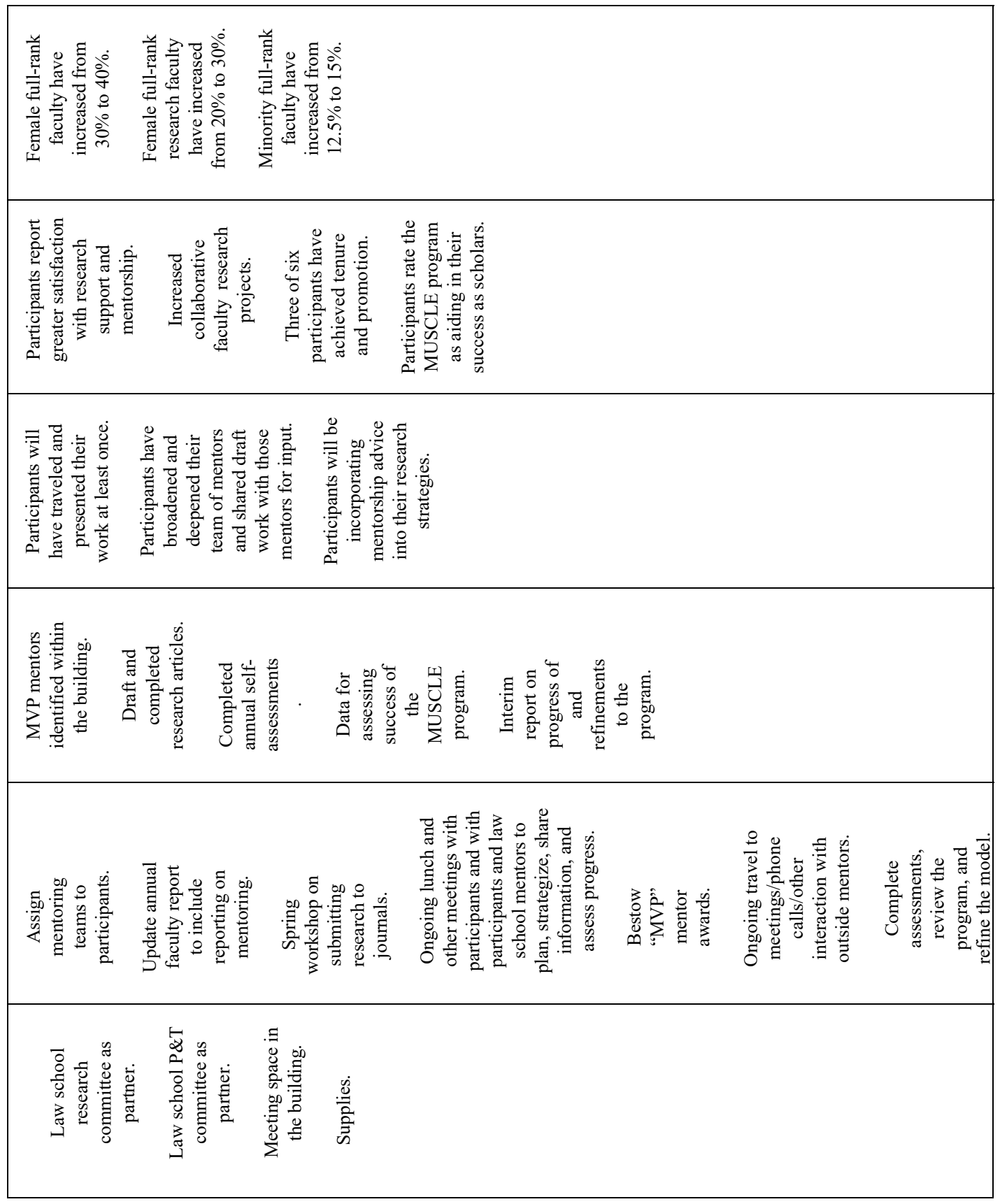

